\title{
Students' Perception of Teachers Nonverbal Immediacy Behavior toward Students' Attitude and Motivation in Learning English
}

\author{
Rendra Kusuma Wijaya \\ kwrendra@gmail.com \\ Universitas Tomakaka Mamuju, Indonesia
}

\begin{abstract}
The objectives of the research were to provide information about students' perception of teachers' nonverbal immediacy behavior toward students' attitude and motivation in learning English. This research is descriptive by nature employing mixed method QUANqual model. Participants of this research were the students of X IIS 2 and XI MIA 4 who were taught by male and female teacher. The data were obtained from questionnaire, group interview, and observation. The data from questionnaire were analyzed by using simple descriptive statistic and the data from interview and observation were analyzed by using interactive model of data analysis procedure consisting data collection, data reduction, and data display, and conclusion drawing. The finding showed that the mean score of students' attitude was 76.56 under category positive attitude. The mean score of students' motivation was 75.43 under category motivated. The students perceived that teachers' nonverbal immediacy behavior influenced their attitude and motivation positively or negatively depending on particularr determinant factors such as religion, culture, and age. The findings led to the onclusion that managing nonverbal immediacy behaviors was very important for teachers because the behaviors could help changing students' attitude from negative attitude became positive attitude and changing students motivation from demotivated became motivated during learning process in the class.
\end{abstract}

Keywords: Nonverbal immediacy behavior, attitude, motivation

\section{INTRODUCTION}

Some students who have negative attitude and low motivation in learning English are usually found in class of English subject as well as in SMA Negeri 1 Mamuju. The negative attitude and low motivation come from many causes such as teachers' communication skills that is not meet the students needs in learning. The communication skills of teachers are not attractive or the teachers do not pay attention to particular small thing important. Finally, negative attitude lead to the low level of motivation and prevent students to acquire good achievement from English subject.

In classroom context, teaching and learning is actually another form of communication. Teacher and students share ideas, knowledge, feeling, or information through from one to another. During the communication, many barriers could become barriers that prevent the ideas, knowledge, feeling, or information transfer well. Nonverbal immediacy behaviors during communication are supposed to overcome the barrier problem in communication and to enhance closeness between teacher and students during communication in the class. 
Some researches done in university suggest that immediacy behaviors have contribution in influencing students attitude or motivation in learning. Velez and Cano (2008) found that there was substantial correlation between immediacy behaviors and students motivation regardless the lecturer tittle professor or non-professor. Bozkaya and Aydin (2007) found that verbal and nonverbal immediacy behaviors had positive influence on learners' social presence during academic tutoring services. It means the behaviors could influence the learners' attitude to feel positive in social context of interaction amongst the learners of academy tutoring services. Other researcher, Roca (2004) revealed that immediacy behaviors have positive correlation students' attendance and their participation in the class. Rasyid (2013) found that the way students favored and did not favored the behaviors are influenced by culture and religion norms.

Regarding the case of attitudes and motivation case at high school of SMA Negeri 1 Mamuju, managing teachers' immediacy behavior could help changing students' negative attitude toward English subject and motivate them to learn more. However, previous researches were focusing only on university level, leaving a gap for the study at high school level of education. Less is known from previous researches about immediacy behaviors in high school level. Managing immediacy behaviors in teaching are teachers' obligation but considering students' perception in doing the behaviors are a good idea too since the students are the subject who learn English in the class.

Based on some students' attitude an motivation in learning English at SMA Negeri 1 Mamuju and the present studies about immediacy behavior, there is a need to investigate on students' perception of teachers' nonverbal immediacy behaviors toward students' attitude and motivation in learning English. This research will elaborate students' perception about the issue and fill the gap in immediacy behaviors in EFL study. Regarding several reasons such as the focus of the study and the tendency that nonverbal immediacy behaviors tend to be abandoned rather that the verbal ones, this research will focus on nonverbal behaviors instead of the verbal ones.

\section{LITERATURE REVIEW Related Studies}

Bozkaya and Aydin (2007 p.76) found that verbal and nonverbal immediacy behaviors had positive influence on the learner's social presence. The learners saw themselves as part of community and learned better when they attend academic tutoring services.

Velez and Cano (2008 p.76-84) investigated professors and non-professors' immediacy in teaching and found that there were substantial correlation between teacher's verbal and nonverbal immediacy and students' motivation regardless they are professors or non professors. Other researcher, Rocca (2004) revealed that immediacy behavior positively correlated with students' attendance and their participation in the class. Rasyid (2014) revealed that there are particular nonverbal immediacy behaviors which are not favorable by the students of undergraduate program majoring in English Education attending the TEFL course in 2013/2014. The ways students favored and did not favor are influenced by culture and religion norms (Rasyid, 2013).

Those previous researches were done at university level with particular background culture. The participants' prior knowledge processed the information about immediacy behavior before finally deciding to respond with particular attitude. The values of proper and improper attitudes were measured by the cultural value that is existed around. 
These conditions leave a gap for this research to investigate the problem at high school level of education. Since the school is immersed at Mamuju Mandarese culture, the students' point of view toward immediacy behaviors will be determined by Mamuju Mandarese cultural view. Aside with that, age difference also will distinguish the way the participants of previous researches and participants of this research in thinking and responding to gender-based teachers' immediacy behaviors.

\section{Theoretical Background}

\section{Theory of Nonverbal Immediacy Behaviors}

Nonverbal immediacy behaviors conveys implicit messages such as emotion and feelings. Nonverbal immediacy behavior has close relation with non-conscious aspect of individual personality (Thomas et. al., 1994). It somehow reflects personality and inner orientation even if someone is not fully aware of doing it so. It is possible caused by genetics or conditioning habits. Mehrabian (1971 p.4-16) stated that nonverbal immediacy behavior always appears in daily life ranging from baby behavior, poker player, dancing, and politician speech in TV show, teachers in teaching, and in all human daily interaction.

Teaching is actually a kind of communication. Teacher and students do send and receive messages activities during the teaching and learning. Hence, teaching and learning involves nonverbal immediacy behaviors. As Mehrabian (1971) suggested that people tend to approach what or who they like and avoid they do not like. During teaching and learning, students may approach their teacher whom they like and avoid whom they do not like. The approach can be in students' attendance and participation during the class (Rocca, 2004). Students aproach to their teacher is an indication that communication barriers are removed or reduced.

More attendance and participation make more experience in learning which will result better affective and cognitive learning (Chesebro and McCroskey, 2001).

Culture determines social value. Since communication happens in the society, it cannot be separated from cultural influences. The value of well-mannered and unwell-mannered in communication is influenced by culture. As part of communication, nonverbal immediacy behavior is somehow also under cultural influence. Rasyid (2013) revealed that culture influences nonverbal immediacy. Particular measures of nonverbal immediacy behavior will give different influence under different culture circumstance. In proximity measures, for instance, sophomore female students will feel uncomfortable if a male lecturer stands and speak too close. It is because the culture considers non-family male-female should not stay too close each other. Another example is eye contact. In particular culture, an inferior should bow head when talking to superior for representing respect.

Velez and Cano (2008) suggested several nonverbal immediacy measures that may be involved in the class such as smile while talking, voice tone variation, relaxed body position, vocal expression, and teaching position (whether sit, stands, or walks). Rasyid (2013) suggested addition such as teaching mood and readiness, movement, punctuality, proximity, physical appearance, and touch. 


\section{Theory of Attitude}

Allport (1954) defined attitude as a learned predisposition to think, feel and behave towards a person or object in a particular way. Katz (1960) defined attitude as the predisposition of an individual to evaluate some symbol or object or aspect of his world in a favorable or unfavorable manner.

Attitude covers three components; the first component is informational component. It is responsible for cognitive process of processing information from attitude object. Therefore, it involves basic knowledge owned before as comparator, assimilator, or assessor. The result of informational component will affect emotional and behavioral component which are how people feel and behave. The second component is emotional component. Emotional component, or often called as affective component, involves all feeling and thought about object or subject. These feelings could be negative, positive, or even neutral. For instance, individual's emotion will be different when talking with lover, police, debt collector, or customer. The third component is behavioral component. Behavioral component is a tendency of a person to behave in particular manner towards an object, subject, or circumstance. The tendencies how to behave are affected by emotional and also informational component. When a stimulus enters the brain, emotional and informational component will process it. The result of the process will affect how the person behaves toward the stimulus.

Nonverbal immediacy behaviors done by teachers in this case are the attitude objects. Students will have attitude toward teacher effort to remove or reduce communication barrier. The attitude could be positive or negative depending how students process the information with their own basic knowledge they have already had. The basic knowledge is growing and acquired continuously based on experience and learning in the society.

\section{Theory of Motivation}

Maslow (1943) theorized that there are five needs of human being namely physiological needs, security and safety, social needs, esteem needs, and self-actualization needs. The desire of fulfilling the needs reinforced by punishment and rewards is called motivation (Skinner, 1938), which according to Rabideau (2005), can be defined as the driving force behind all the actions of an individual. Therefore, motivation is a power that motorized people to do a goal-oriented activity.

Motivation is divided into two kinds. The first is intrinsic motivation. It is emerged from inner self of someone. The second is extrinsic motivation. It is arrived from outside of someone. In Skinner definition, the intrinsic motivation is the desire to fulfill needs as also Maslow said. The punishment and reward through conditioning will be the external motivation. Punishment motivate someone to avoid mistakes and reward will strengthen the desire to fulfill the needs.

In classroom context, teachers' nonverbal immediacy behaviors are extrinsic motivation. Students' attitudes toward teachers' nonverbal immediacy behaviors are the determining the motivation emerged. Uno (2011) set out some attitudes that could be indicators of motivation they are have passion and will of succeed, feel encouraged \& enthusiastic, have expectation and ideals, feel appreciated and attracted, have needs in learning, and feeling comfortable in conducive learning environment. 


\section{The Concept of Gender}

Puspitawati (2012) uses the term "gender" to refer to the economic, social, political, and cultural attributes and opportunities associated with being female and male, which may be defined differently among cultures and changes over time. Gender should be conceptualized as set of relation between man and woman existing in social institution and interpersonal interaction. Butler (1990), stated that at ideological level, gender is formatively created.

Gender is also property of ongoing interaction —instead of individuals' propertybetween actors (men and women) and structures (cultural norms) with very great variation among men and women. On the other hand, sex is divinely given. The ability of producing sperm cells is the ability of male sex while the ability of producing the egg cell is female ability. The task of pregnancy and breast feeding are divinely created by the Almighty God.

In classroom context, the gender different of teachers will make students responding differently. Since gender is culturally formed, cultural norms play important roles for male-female interaction. In high school age, students are in period of puberty that will respond differently toward different gender. Affective and cognitive elements of attitude will process the information about gender difference based on the basic knoledge formed in the culture. Therefore, different response toward gender different in the culture is inevitable based on the surrounding cultural norms.

\section{Malaqbiq in Mandarese Culture}

Malaqbiq $^{l}$ is a term refers to high and noble moral value that became one of principles for Mandarese people in living the life. People need a moral value in living the life to reach better life and emerge courteous civilization. The moral value has been becoming Madarese people's life principle since long ago. In narrower view malaqbiq could also mean how people possess high and noble attitude in thinking, feeling, and behaving. Malaqbiq in Mandarese culture is probably similar to Malebbi concept in Buginese culture or Labbiri concept in Makassarese culture but each of them must have their own characteristics distinguishing one to another. Malaqbiq is divided into two categories namely malaqbiq kedo and malaqbiq gauq (Munir, 2015).

Malaqbiq kedo is keeping all attitudes (thought, feeling, and behavior) to be in line with rules of religion. As the majority of Mandarese people embrace Islam as their religion, Malaqbiq kedo value was highly influenced by Islamic rules. Yet, it is not possible for other cultural value was adopted as value of malaqbiq kedo along with Islamic rules.

Malaqbiq gauq is moral value that is related high and noble behavior in daily life. Therefore, Malaqbiq gauq give moral value in social interaction such as when speaking with others, doing business, helping each other, or not betraying trusts or mandate from other people. Honesty and sincerely in teaching are also part of malaqbiq gauq.

\footnotetext{
${ }^{1}$ The letter $q$ is pronounced as $k$ in Indonesian word tida $\underline{k}$ or $\varepsilon$ in Arabic word

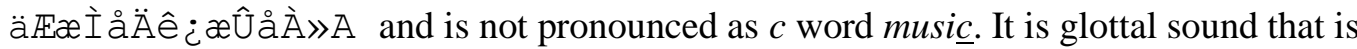
not exist in English.
} 
In classroom context, the philosophy of malaqbiq will influence how students perceive about teachers' nonverbal immediacy behaviors. Which behaviors are proper or improper will be determined by using the philosophy. The polite interaction between younger and older people or the interaction between teachers and students are regulated in the culture even though it is not written regulation.

\section{METHOD}

\section{Design and Participants}

This research is descriptive by nature employing mixed method QUAN-qual model. This research was explanatory research in which the quantitative data will be further explained by the qualitative ones (Gay et.al, 2006 p.490). The total participants were 60 students consisting 26 students of X IIS 2 who taught by female teacher and 34 XI MIA 4 who were taught by male teacher.

\section{Instruments and Procedure}

The instruments of this research were questionnaire, interview, and observation. The data was collected by handing out questionnaire to the participants, doing interview to a number of selected participants, and doing observation in the class when teaching and learning process was running. The data from questionnaire were analyzed by using simple descriptive statistic utilizing mean score and modus. The data from interview and observation were analyzed by using interactive proceess of data analysis (Miles \& Huberman, 2007) consisting data collection, data reduction, data display, and conclusion drawing.

\section{RESULT AND DISCUSSIONS}

\section{The Students' Attitude}

The following table shows the result of questionnaire about students' perception toward nonverbal immediacy behaviors on their attitude in learning.

\begin{tabular}{|c|c|c|c|c|c|}
\hline \multirow{2}{*}{ No. } & \multirow{2}{*}{ Score } & \multicolumn{2}{|c|}{ Frequency } & \multirow{2}{*}{ Total } & Classification \\
\cline { 3 - 4 } & & X IIS 2 & XI MIA 4 & & \\
\hline 1 & $84-100$ & 2 & 3 & 5 & Strongly Positive Attitude \\
\hline 2 & $68-83$ & 24 & 29 & 53 & Positive Attitude \\
\hline 3 & $52-67$ & 0 & 2 & 2 & Neutral \\
\hline 4 & $36-51$ & 0 & 0 & 0 & Negative Attitude \\
\hline 5 & $20-35$ & 0 & 0 & 0 & Strongly Negative Attitude \\
\hline 6 & $\bar{X}$ & 76.98 & 76.24 & 76.56 & Positive Attitude \\
\hline 7 & Mo & $68-83$ & $68-83$ & 53 & Positive Attitude \\
\hline
\end{tabular}

Nonverbal immediacy behavior would give positive influence on attitude only when it was done well and accordingly. Teacher's nonverbal immediacy behaviors remove physical and psychological distance between communicator (in this case was a teacher) and communicants (in this case were students). Then, when the barriers were removed or reduced, the students and their teacher were close each others. Emerging comfortable teaching and learning environment would be emerging. 
Generally, people liked comfortable things and would do effort to approach it. Therefore, nonverbal immediacy behaviors had important role to emerge comfortable interaction during teacher-students communication in the classroom.

\section{The Students' Motivation}

The following table shows the result of questionnaire about students' perception toward nonverbal immediacy behaviors on their attitude in learning.

\begin{tabular}{|c|c|c|c|c|c|}
\hline \multirow{2}{*}{ No. } & \multirow{2}{*}{ Score } & \multicolumn{2}{|c|}{ Frequency } & \multirow{2}{*}{ Total } & \multirow[t]{2}{*}{ Classification } \\
\hline & & X IIS 2 & XI MIA 4 & & \\
\hline 1 & $84-100$ & 2 & 1 & 3 & Strongly Motivated \\
\hline 2 & $68-83$ & 22 & 31 & 53 & Motivated \\
\hline 3 & $52-67$ & 2 & 2 & 4 & Undecided \\
\hline 4 & $36-51$ & 0 & 0 & 0 & Demotivated \\
\hline 5 & $20-35$ & 0 & 0 & 0 & Strongly Unmotivated \\
\hline 6 & $\bar{X}$ & 76.18 & 74.84 & 75.43 & Motivated \\
\hline 7 & Mo & $68-83$ & $68-83$ & $68-83$ & Motivated \\
\hline
\end{tabular}

Nonverbal immediacy behavior would give positive influence on motivation only when it was done well and accordingly. Teacher's nonverbal immediacy behaviors remove physical and psychological distance between communicator (in this case was a teacher) and communicants (in this case were students). Then, when they were close each others, comfortable teaching and learning environment would be emerged. Generally, people liked comfortable things and would do effort to approach it. In other word, the students were motivated to approach comfortable learning atmosphere. Mehrabian (1971) said that people would tend to approach what they like and avoid what they dislike. Like became the motivation of approaching.

Teacher's nonverbal immediacy behavior became an external motivation for the students. The comfortable feeling during teaching and learning made student enjoyed the English learning process. It erased the boredom feeling and any uncomfortable things. Then, it motivated the students to learn English. Uno (2006:23) stated that the existence of motivation could be seen from six indicators. Two of them were feeling attracted and comforted in learning.

Attraction and comfort were common things that people sought in life. In students' context, attraction to English and feeling comfort when learning it were what students sought yet not all found and experienced it. In line with Mehrabian's theory that people tend to approach what they like and avoid what they dislike, the attraction and comfort feeling during learning triggered by teacher's nonverbal immediacy behaviors were the things the students liked and they would approach them. 
When students approach something because they liked it, it means the motivation was exist though as external motivation.

\section{The students' perception on teachers' nonverbal immediacy behaviors toward their attitude and motivation in learning}

Based on the interview and observation, the influence of teachers' nonverbal immediacy behaviors were categorized into two main categories namely the influence that is regarding gender and the influence that is not regarding gender.

Appearance, smile and eye contact, proximity, postures and body position, and touch were the behaviors that influenced students' attitude and motivation regarding gender. On other hand, teaching mood and readiness, punctuality, voice usage, and movement were the behaviors that were not regarding gender in influencing students' attitude and motivation in learning English.

\section{a. Appearance}

The students perceive that particular appearance of male and female teacher could have different influence to students. Male teacher's hair cut could make male students jealous if it was more than $3 \mathrm{~cm}$. The school rules stated that male students should have no longer than $3 \mathrm{~cm}$-long haircuts. Growing hair more than $3 \mathrm{~cm}$ was considered as infraction to school's rules. Similarly, female students were jealous to female teachers who wore veil but wore tight and shorter skirt. It was because female students were forbidden to wear shorter skirt if they wore veil. However, in male students' point of view, they liked and attracted to learn if young female teacher wore tight and shorter skirt. Looking from the age of the students, their attitude toward teachers' appearance was because they were in age of puberty. The reasoning ability and the opposite gender attraction were growing along with their age (Batubara, 2010., Fischer et.al.,2003). In their opinion, there was no difference between teachers and students in regard to haircut or skirt length. If students had to obey the rules, the teachers had to obey the rules too in the first place because teachers are example for students. Thus, in the age of puberty, the understanding about opposite gender attraction is growing. Therefore, the students were attracted to opposite gender appearance such as male students attracted to female teacher who wore tight and shorter skirt.

When teachers' appearance was appropriate, interesting, and attractive according to students' point of view, the students felt comfortable and close to their teachers. Students had no reluctance to ask to teacher about unclear explanation. The attitudes were the indication that students were motivated in learning. In vice versa, when the teachers' appearance provoked students' jealousy and the feeling of injustice, the students had negative attitude and finally influenced the students' motivation in learning. Furthermore, in cultural point of view, when someone dressing as the religion teach to do it, the person will be consider as malaqbiq person.

\section{b. Smile and eye contact}

The students point of view, teachers' smile and eye contact was important for them is it was done in appropriate length of duration and appropriate frequencies. The students felt comforted and appreciated to the teacher who did smile and eye contact properly. Prolonged eye contact was supposed as offensive acts and shorter eye contact was 
supposed as ignorance or no attention. Smiling represented mood in teaching. Serious face with no smile and prolonged eye contact were able to control or prevent students from doing unwanted activities in the classroom.

Smiles and eye contact had important role during the class activity. Smile and eye contact could give positive and negative response from students in the class. Appropriate smiling and doing eye contact could make students felt comfortable during teaching and learning. It was because smile and eye contact was a sign of immediacy and care (Jaskolka, 2011:114) between teacher and students. Enjoyable smile released from a dear and close person showing affection and intimate. Therefore, teacher smile and eye contact made students looked relaxed and enjoyed the smile and eye contact because there were sense of close, intimate, care, and affection from teacher. On the other hand, eye contact could also be a sign of offensive act. Sharp and long stare could mean prevention for students from doing any unwanted activities in the classroom. Therefore, using appropriate smile and eye contact were important to gain the expected result of teaching and learning process.

In cultural point of view, managing smile and eye contact well could made a person became malaqbiq person. In Mandarese context, malaqbiq could mean highly polite attitude. Smiling appropriately and doing eye contact properly when communicating were supposed as polite attitude. Smiling was associated with friendliness while eye contact was supposed as attention and appreciation to communicating partner. It was often found in the society that particular eye contact could trigger fight among two people. Particular smile over inappropriate people also could be considered as impolite such as a man smiling to a woman flirty while she had already had spouse.

Therefore in malaqbiq concept, managing smile and eye contact properly was important to have highly polite attitude. Finally, when the students were comfortable and attracted to a malaqbiq teacher with good smile and eye contact, they were motivated in learning because they were approaching the teachers with good smile and eye contact.

\section{c. Proximity}

Students' perception toward teacher-students proximity was depending on several factors such as teacher's friendliness, mood, voice clarity and audibility, body odor, and gender. When the teacher was friendly, had good mood, had clear and audible voice, the students felt comforted to be closer to their students. Gender difference also made students feel awkward to be closer to teacher with opposite gender. The proximity between the students and the teachers were also showing the level of immediacy between them.

Friendly teacher made teaching and learning activity become comfortable. Friendly teacher had good mood in teaching and interacting with students. The friendliness made students feel comfortable in learning. On the other hand, unfriendly teacher was prone to violate students when he or she released the bad mood feeling. This phenomenon could explain the students' perception that they were okay to be closer in proximity with a friendly teacher.

Adjusting proximity also had purpose to make teacher's voice audible to all part of classroom. If the teacher had clear and audible voice reaching all part of classroom, being farther or closer was not a problem for students. 
The problem appeared only when the teacher voice was too low or too loud. So, adjusting proximity would help to remove or reduce the communication barrier.

In Mandarese culture, people tended to adjust the proximity when communicating. For instance, when a younger person talked to an older person, it is considered as impolite if the younger person does not approach the older person. In inviting someone to particular activity such as marriage the person who brings invitation should be sit in particular appropriate proximity before speaking to invite to the marriage party. In classroom context, the teacher was in superior position of freedom to talk to students in particular proximity. However, for appreciating the students, the adjustment of proximity was required.

\section{d. Postures and Body Position}

The students perceived that postures and body position did not influence students very much. All were depending on the teacher's skills in teaching. However, they had view about the teachers' body position that was possessing very relaxed body position was good for teacher's image.

Too sturdy body postures gave soldier image for the teacher but have more power to control students' unwanted activities. Therefore the teacher would look scary and uphold extra disciplines. Thus, the students could be motivated because they were afraid of the teacher with extra disciplines. However, there was a big chance for teacher to put the students under forced instead of motivated.

Jaskolka (2011) stressed the importance of body postures and body position in communication. The relaxed and energized position gave alert of enthusiastic and interested in the topic of communication. Because of the image of enthusiastic, interested and the position also gave space for third parties to join the communication. In the classroom context, it could mean that the teacher was enthusiastic and interested in teaching. The space emerged from the body position gave more chance to students to join the class activity during teaching and learning.

e. Touch

Students perceived that teacher's touch in particular conditions were motivating but mostly were sensitive. Only a narrow part of body was acceptable for touch but still had to consider the intention and the way to touch the students with opposite gender. Shoulder's patting and backhand kissing were considered as acceptable for touching. Female students would have tendency to avoid male teacher's touching and the male students did.

Though the students' opinion about shoulders patting could motivate students in learning, during the class they were never touched by teahcer. The only touch was backhand kissing when the students were arrived at school and when the school was over. Hand kissing, in Mandarese culture, is supposed as malaqbiq behavior done by inferior o superior in order to respect the superior. In classroom context, teachers were superior to students. Therefore, students were doing back-hand kiss for their teacher who was superior than them. Though the Islam rules that touching opposite gender is forbidden, the students were keeping on hand kissing the teachers. Teachers were people that students appreciate. 
Further, the awareness of applying the religious norm was not as high as at university level as founded by Rasyid (2013). On the other hand, there are some scholars of Islam who allowed to do handshake between male and female.

\section{f. Teaching Mood and Readiness}

Teaching mood and readiness made students think about the teacher's proficiency in teaching. When students lose their believe that the teacher was proficient in teaching English, the students would have negative attitude and demotivated in learning English.

A teacher with the good teaching readiness behaviors made students had trust to the teacher that the teacher was really capable in teaching the students. They thought that obstacles might be hampered their way in learning English yet and they believe their teacher could deal with the hamper and help the students. The positive thought of the students then would transform to their feeling in learning. They would feel comfort in learning, love it, and always be curious to the English subject.

Due to the teacher's good mood, the students' mood in learning also could become good. They would have positive thinking about their teacher and have good feeling during the class. They would behave well such as actively look for help when found out obstacles in learning English, never again missed the class to avoid English, and became more diligent than they used to be. In vice versa when teacher's bad mood, students would tend to avoid their teacher and felt of being immersed in uncomfortable learning situation. Therefore, teacher's mood, whether good or bad, influence students mood too.

When the students felt comfortable in conducive learning environment, the motivation would emerge. As always mentioned before, students sought comfortable learning condition as people generally sought for comfortable things in life.

\section{g. Punctuality}

The finding of punctuality shows that the students could have negative or positive attitude toward the punctual teacher. Positive attitude mainly came from teacher who ended the class on time. Negative attitude emerged toward punctual teacher who did not give tolerance to latecomers and when the teacher was late he/she just entered the class and taught. Students demanded equality for both because a teacher is an example. Positive attitude emerged when teacher, in the top most, ended the class on time. The next was when the teacher was starting the class on time and had tolerance for latecomer students or a punctual teacher who applied the same rules for him and the students dealing with lateness. There were no gender factors influencing the behavior.

Students woud be motivated to learn when the teacher became the example in punctuality. Teacher might ban students when they were late but should apply the same rule when the teacher was late too. It was a challenging activity for students to alwasy be on time as their teacher did it so. However it would be demotivating if the teacher set very punctual rules for students but the teacher did not obey his own rules.

h. Voice

Varying the volume level of voice would make the students' attitude toward English subject positive as long as the volume level was clear and audible. 
The variation was important to make the atmosphere during the class interesting and far from boredom. The clarity and audible voice was important to make sure the message was transferred correctly. Too loud volume of voice would disturb not only the class but also the next neighboring classroom and emerged image of anger. On the other hand, too low voice volume usage would make students did not catch the messages delivered. Too low voice tone also made teacher look sad. It was also non-audible so the students could not hear the voice and understand the meaning delivered by the teacher.

During teaching and learning activity in the classroom, voice became the most important media in delivering verbal messages from teacher to students. Varying the tone of voice would be necessary for particular expression during teaching and learning. For stressing on particular point of information, a teacher could use particular voice volume and intonation. In particular part of the time, using varying voice volume level would dramatize the teaching and learning situation. It would make the teaching become interesting and prevent the students from boredom. Then when students feel interested they would approach their teacher and have good attitude toward the English subject.

\section{i. Movement}

Teacher's movement could influence students' attitude positively in learning English. However, teacher's movement in examination time could influence students' attitude negatively. Teacher's movement when learning was supposed as teacher's effort to interact with students and help them out when finding difficulties. Interaction with students got the teacher immediate to students. Moving around when learning also could control class from doing unwanted things such as being noisy, playing around, or doing other than teacher's instruction.

Teacher's movement when examination time made students have negative attitude. Some students were nervous and under tense. There were two kinds of students during examination they are the cheating students and the honest students. For the cheaters, the tense and nervousness was caused by the feeling of afraid of being caught. For the honest students but had lack confident, the tense and nervousness was caused by their unconfident feeling of what they did during examination.

Moving around the class has function as controller, encouragement, and interaction. Controlling function would prevent the students from doing unwanted behavior in the class.

Encouragement function would give help to students who need help from teacher related to the lesson or else. Interaction function had function to get the teacher more immediate to the students. Though moving teacher could cause some tense and nervousness during the examination time, it would prevent students from cheating or making noise during the exam that would disturb their other friends. However, when teacher was in bad mood, students preferred their teacher staying away from them because they had experience that teacher in bad mood tended to be angry easily and released the bad mood to students by particular means such as pinching, hitting, or slapping.

As discussed before, there is tendency that when students' attitude was good toward teachers' nonverbal immediacy behaviors, their external motivation in learning would be good too. The tendency was because when students feel comfortable with the teacher, the students approached the teacher. 
Mehrabian (1971) said that people tend to approach what they liked and avoid what they disliked. Approaching because the feeling of like is actually a trait of motivation. The same things happen with avoiding because of dislike that is also a traits of motivation but in reverse direction. If approaching the teacher because the students like the teacher is supposed as motivated, avoiding the teacher because the students disliked is supposed as demotivated.

\section{CONCLUSIONS AND SUGGESTIONS}

Three points are concluded in this research.

First, Nonverbal Immediacy behavior has influence on students' attitude. The attitude could be negative or positive depending on the behaviors done by teacher. Second, Nonverbal Immediacy behavior has influence on students' motivation. The motivation could be larger or smaller depending on the behaviors done by teacher. And the third, from nine behaviors of the immediacy behaviors investigated in this research, students perceived that five behaviors (appearance, smile and eye contact, proximity, postures and body position, and touch) have gender as determinant factors in influencing students attitude and motivation and the other four (movement, teaching mood and readiness, punctuality, and voice usage) did not have gender as determinant factors in influencing students attitude and motivation.

Four suggestions are given based on the conclusion of the research as follow:

This research showed that students perceived that their teachers' nonverbal immediacy behaviors could make their attitude and motivation positive or negative. Therefore, a teacher of senior high school should manage his/her nonverbal immediacy behavior well and consider the cultural norms in doing the behaviors. Finding of this research could be a guidance to determine which one positively influences attitude and which one negatively influences attitude; and also which one is motivating and which one is demotivating.

In applying particular nonverbal immediacy behavior, a teacher should be aware about gender influence in nonverbal immediacy behavior. The same action could have different meaning for different gender. This is because in particular culture, particular patterns of relation among male and female are exist. Since the students live in the culture, they will likely respond based on general view of the cultural norm where the school is immersed.

A teacher should be aware of other determinant factors that might determine the influence of nonverbal immediacy behaviors on students' attitude and motivation.

A teacher should apply nonverbal immediacy behaviors that can make students have positive attitude and strong motivation in learning English.

\section{REFERENCES}

1971. Silent Messages. Belmont California: Wadsworth Publishing Company, Inc. 
1972. A Nonverbal communication. Chicago, IL: Aldine'Atherton. Departement of Psychology. University of California, Los Angeles.

--. 2007. Effective Room Arrangement. Education World. Available for download http://web.uvic.ca/ gtreloar/Articles/Classroom\%20Management/Effective\%20R oom\%20Management.pdf

2012. "Pengaruh Penampilan Guru Pkn Terhadap Motivasi Belajar Siswa"

Tarbawi, Jurnal Pendidikan Islam Universitas Pendidikan Indonesia Vol. III No.3. Desember 2012. Jakarta: Elan UPI. Last accessed at January 3, 2015. http://jurnal.upi.edu/tarbawi/view/1865/pengaruh-penampilan-guru-pknterhadapmotivasi-belajar-siswa.html

Alderfer, Clayton. 1972. Existence, Relatedness, and Growth: Human Needs in Organizational Settings. New York: The Free Press.

Allport, Gordon. 1954. The Nature of Prejudice. Reading, MA: Addison-Wesley.

Alsayed, Mounawar. 2003. "Factors that Contribute to Success in Learning English as Foreign Language." dalam Damascus Univeristy Journals, Vol.9. No.1+2. p.2144

Aritonang, Keke T. 2008. Minat dan Motivasi dalam Meningkatkan Hasil Belajar Siswa. Jurnal Pendidikan Penabur - No.10/Tahun ke-7/Juni 2008.

Batubara, Jose RL. 2010. "Adolescence Development" Sari Pediatri Volume 12. No.1 Juni 2010. Jakarta: Fakultas Kedokteran Universitas Indonesia.

Birdsong, D. 2004. Age and Second Language Acquisition and Processing: A Selective Overview. University of Texas: Austin

Bozkaya, Müjgan and Aydin, İrem Erdem. 2007. The Relationship between Teacher Immediacy Behaviors and Learners' Perceptions of Social Presence and Satisfaction in Open and Distance Education: The Case of Anadolu University Open Education Faculty. The Turkish Online Journal of Educational Technology - TOJET October 2007 volume 6 Issue 4 Article 7 ISSN: 1303-6521.

Butler, Judith. 1990. Gender Trouble. Feminism and the Subversion of Identity. Routledge: New York.

Cherry, Kendra. 2014. What is Motivation? (Online) http://psychology.about.com/od/mindex/g/motivation-definition.htm Retrieved May 8, 2014.

Chesebro, J.L. and McCroskey, J.C. (2001). The relationship of teacher clarity and immediacy with student state receiver apprehension, affect, and cognitive learning. Communication Education, 50, 59-68.

Chovski, Ivone. 2013. "Eye Contact and Social Interaction." Successful communications, flirts and relationships. Online. Last retrieved: October 16, 2014. http://ivonechovski.wordpress.com/2013/09/17/eye-contact-and-socialinteraction/

Christine, Deborah and Viner, Russel. $20 \mathrm{C}$

149 30, 5 February 2005. Bmj.com

sscence Development" BMJ Volume

Donald, Hoton and Wohl, R. Richard. 2006. "Mass Communication and Para-Social Interaction: Observations on Intimacy at a Distance." Particip@tions Volume 3, $\begin{array}{lllll}\text { Issue } & 1 & \text { (May 2006). } & \text { Retrieved }\end{array}$ http://www.participations.org/volume\%203/issue\%201/3_01_hortonwohl.htm (october 16, 2014).

Febrilia, I \& Warokka, A. 2011. "The Effects of Positive and Negative Mood on University Students' Learning and Academic Performance: Evidence from Indonesia" The 3rd International Conference on Humanities and Social Sciences 
April 2, 2011. Faculty of Liberal Arts, Prince of Songkla University Proceedings- Factors Affecting English Language Teaching and Learning

Fischer, Kurt. Yan, Zheng. \& Stewart, Jeffrey. 2003 "Adult Cognitive Development: Dynamics in Developmental Web." Handbook of Developmental Psychology. Edited by Jaan Valsiner and Kevin J. Connloy. New Delhi: Sage Publication.

Gay, L.R., Mills, G.E. \& Airasian,P. 2006. Educational Research. Competencies for Analysis and Aplication $8^{\text {th }}$ Edition. New Jersey: Pearson Prentice Hall

Giroux, Alexandra. (2011). Proximity in Multicultural Classes. The Hague University. Online. http://www.alexandragiroux.net/proximity-in-multicultural-classes/ Last Retrieved at October 16, 2014.

Green, Bert F. (1953) "Attitude Measurement," Handbook of Social Psychology, ed. Gardner Lindzey, Vol. 1 Addison-Wesley.

Harmer, Jeremy. 2007. The Practice of English Language Teaching. 4th Edition. Longman: London

Hess, U., Beaupré, M.G. Cheung, N. (2002). "Who to whom and why - cultural differences and similarities in the function of smiles." dalam Millicent Abel (Editor.) An empirical reflection on the smile, pp. 187-216. New York: The Edwin Mellen Press

Hess, Ursula. and Bourgeois, Patrick. 2010. "You smile-I smile: Emotion expression in social interaction." Biological Psychology 84 (2010) 514-520 last downloaded October 17, 2014. from http://www.ursulakhess.com/resources/HB10.pdf

Hoppe, Elliot. 2011. "The Comfort Zone: Phisical Proximity and Sales." Elliot Hoppe. Communication Skills for Bussines Development. Paramount Learning. Available Online http://www.eliothoppe.com/articles/20091031physical_proximity.html Accessed on November 5, 2015

http://neila.staff.ugm.ac.id/wordpress/wp-content/uploads/2009/09/bab1-attitude.pdf

http://www.mu.ac.in/myweb_test/TYBA\%20study\%20material/Gender\%20\&\%20Soc..p df

Jones, Fred. 2007. Tools for teaching: Disciplines. Instruction. Motivation. Second Edition. Santa Cruz: Frederick H. Jones and Associates. Inc.

Jones, Jhon F. The theory of attitude formation and change and its application to social group work $\quad$ Downloaded from http://web.psych.utoronto.ca/psy320/Required\%20readings_files/week2-2.pdf on May 20, 2014

Kaizer, Suzan B., Nagawasa, Richard H., and Hutton, Sandra. 1991. "Fashion, Postmodernity and Personal Appearance: A Symbolic Interactionist Formulation" Symbolic Interaction Volume 14, Issue 2, pages 165-185. (Online. Retrieved at October 16, 2014)

Katz, Daniel. 1960. The Functional Approach to the Study of Attitudes, Public Opinion Quarterly, 24, pp. 163-204. http://poq.oxfordjournals.org/content/24/2/163.abstract retrieved at

Mandegar, Syarifuddin. 2015. Trilogi Malaqbiq: Sebuah Pengantar. Mamuju: Kandora News. http://www.kandoranews.com/trilogi-malaqbi-sebuah-pengantar/ accessed on November 1, 2015

Martin, Brett AS. 2003. The Influence of Gender on Mood Effects in Advertising. Psychology \& Marketing, Vol. 20 (3): 249-273 (March 2003) Published online in Wiley InterScience (www.interscience.wiley.com) 2003 Wiley Periodicals, Inc.

Maslow, Abraham Harold. 1943. A Theory of Human Motivation. Psychological Review, $50,370-396$. 
Mehrabian, Albert. 1969. Some referents and measures of nonverbal behavior. Behavioral Research Methods and Instrumentation, 1, 213-217.

Meyes, Annabele and Andeson, Sofia. 2010. "How Teacher Positioning in the Classroom Affect the On-Task Behavior of Students." e-Journal of Students of Research. Volume 2. Number 1. P.1-9 Shippenberg: Department of Teacher Education Shippenberg University. Downloaded http://webspace.ship.edu/ejournal/contents/sp10/final/positioning.pdf $\quad$ last accessed on October 16, 2014.

Miles, Matthew B. and Huberman, A. Michael. 1994. Qualitative Data Analysis. $2^{\text {nd }}$ Edition. London: Sage Publication Ltd.

Munir. 2015. Unpublished thesis. Pascasarjana UNM

Muňoz, Carmen. 2010. "On How Age Affects Foregin Langauge Learning" dalam Advances in Research on Language Acquisition and Teaching. University of Barcelona: Barcelona. p.41

Nadler, R.T., Rabi, Rahel. and Minda, JP. 2010. "Better Mood and Better Performance: Learning Rule-Described Categories Is Enhanced by Positive Mood" Psychological Science, December 2010; vol. 21, 12: pp. 1770-1776.

Naem, Muhammad Bilal and Li, Zili. 2011. Factors affecting attitudes - A study of immigrants' attitude towards the brochures and website of Växjö Kommun. Kalmar Växjö: Liennè Universitetet

Nirmasanti, Nirmasanti. 2014. The analysis of Proximity as non-veral communication in the classroom interaction at junior high school. Program Pascasarjana UNM: Makassar. Unplished thesis.

O’Neill, Robert. 1994. Teacher-talk in the language class.

Pathan, Swaleha S. 2010. "Adolescent' Attitude toward Self" International Refereed Research Journal: Journal of Arts, Science, and Commerce Volume 1, Issue 1 October 2010.

Puspitawati, Heiren 2009. Teori Gender dan Aplikasinya dalam Kehidupan Keluarga. Departemen Ilmu Keluarga dan Konsumen. Fakultas Ekologi Manusia. Institut Pertanian Bogor: Bogor

Puspitawati, Heiren. 2012. Gender dan Keluarga: Konsep dan Realita di Indonesia. PT IPB Press: Bogor.

Rabideau, Scott T. (2005). Effects of Achievement Motivation on Behavior. Rochester Institute of Technology. Retrieved from: http://www.personalityresearch.org/papers/rabideau.html

Rabideau, Scott T. 2005. "Effects of Achievement Motivation on Behavior." Paper of SAPA Project Test (online) http://www.personalityresearch.org/papers/rabideau.html last retrieved on May $8,2014$.

Rahman, Khairul Anuar A. 2012. "Effective Teacher Disposition: Personality Traits and Communication Skills." Akademika 82 (2) p.37-44. Universiti Kebangsaan Malaysia. Available for download http://www.ukm.my/penerbit/akademika/ACROBATAKADEMIKA822/Akademika\%2082\%282\%29Chap\%204-locked.pdf Accessed at October 17, 2014

Rasyid, Muhammad Amin. 2013. Verbal and Non-Verbal Immediacy in EFL Classroom. Faculty dalam International Seminar of ELT. Program Pasca Sarjana UNM.

Reis, Harry T.; Wheeler, Ladd; Spiegel, Nancy; Kernis, Michael H.; Nezlek, John; Perri, Michael .1982. "Physical attractiveness in social interaction" Journal of 
Personality and Social Psychology, Vol 43(5), Nov 1982, 979-996. (Online) last Retreived on October 16, 2014. http://psycnet.apa.org/psycinfo/1983-21061-001

Rocca, K.A. (2004). College student attendance: Impact of instructor immediacy and verbal aggression. Communication Education, 53, 185-195.

Rudman, L.A., 2004. Source of implicit attitudes. Current Directions in sychological Science, Vol. 13, pp.79-82.

Ryan, Richard and Deci, Edward. 2000. Intrinsic and Extrinsic Motivation: Classic Definition and New Direction. Contemporary Educational Pschology 25. 54-67. Academic Press (Online). Downloaded from www.idealibrary.com May 4, 2014.

Singh, KJ. 2013. What is Attitude and what are the components of Attitude? (online) http://www.mbaofficial.com/mba-courses/human-resource-management/what-isattitude-and-what-are-the-components-of-attitude/ retrieved May 23, 2014

Sinring, Abdullah. 2015. "Gaya Komunikasi dalam Pembelajaran: Tinjauan Psikologi Pendidikan" Kuliah Umum pada PPL3 Studi Komparatif FKIP Universitas Tomakaka Mamuju. Pondok Madinah Makassar, 26 Oktober 2015 Makassar.

Sitompul, NC. 2009. Perilaku Komunikasi Nonverbal Guru dalam Kelas Pembelajaran: Maknanya bagi Pembelajaran Siswa Sekolah Menengah Atas. Pascasarjana Universitas Negeri Malang. Desertasi

Skinner, B.F. 1938. The Behavior of Organisms An Experimental Analisys. New York: Appleton Century Crofts, Inc.

Sunan Tirmidhi. Android eBook Software by Girfa eSuite. Available at Google playstore.

Thomas, Candice E., Richmond, Viginia P. and McCroskey, James C. 1994. "The association between nonverbal immediacy and socio-communicative style." Communiation research reports, Volume 11, Number 1. Mortgantown: West Virginia University.

Uno, Hamzah B. 2006. Teori Motivasi dan Pengukurannya. Analisis di Bidang Pendidikan. Jakarta: Bumi Aksara

Uyanne, Michael C. \& Oti, Obianju Julianna. 2012. "The Linguistic Functions of Some Nonverbal Communication Features Operating as the Sub-plane of Language Use" AFRREV International Journal of Arts and Humanity. Vol. 1 (4) November 2012. Pg. 98-111. Bahir Dar: Ethiopia. Available for download at: http://www.ajol.info/index.php/ijah/article/viewFile/106408/96355 last retreived at October 18, 2014.

Veira, Ingrid. 2014. Great Teachers. The teacher's voice. Available Online. Last retrieved October 18, 2014. http://pearsonclassroomlink.com/articles/1110/1110_0502.htm

Velez, Jonathan J. and Cano, Jamie (2008) "The Relationship between Teacher Immediacy and Student Motivation" Journal of Agricultural Education Volume 49, Number 3, pp. 76 - 86. Ohio: Ohio State University

Winardi, 1992. Manajemen Perilaku Organisasi. Bandung: PT Citra Aditya Bakti.

Yanfen, Liu. and Yuqin, Zaho. 2010. "A Study of Teacher Talk in Interactions in English Classes." Chinese Journal of Applied Lingistics (Bimonthly) Vol.33 No. 2. Harbin Institute of Technology. Available download in http://www.celea.org.cn/teic/90/10060806.pdf last accessed October 17, 2014.

Zhang, C. (2009) "A Study of Age Influence in L2 Acquisition" Asian Social Science Journal Vol.5 No.5 May 2009. Qingdao University: Qingdao 